\title{
Technology of production of polystyrene concrete using solar energy
}

\author{
Lyazat Aruova ${ }^{1 *}$, Nabi Dauzhanov ${ }^{1}$, Zhumabeke Ospanova ${ }^{1}$, Shamshygaim Toleubayeva ${ }^{1}$ \\ and Aizhan Utkelbaeva ${ }^{2}$ \\ ${ }^{1}$ Eurasian National University named after L.N. Gumilev, Kazakhstan Republic \\ ${ }^{2}$ Kyzylorda state university named after Korkyt Ata, Kazakhstan Republic
}

\begin{abstract}
The energy of solar radiation is a powerful energy reserve at the surface of the globe which is about twenty billion $\mathrm{kW}$. This amount of energy is more than 100 times greater than the amount of necessary energy for the whole planet; besides the usage of this powerful energy radiator is not associated with polluting substances that pollute the planet. The usage of solar energy nowadays is very important, as the problem of using traditional energy resources is especially acute, because of their irreplaceability and increase in their cost.

At the plants of the Republic of Kazakhstan for the industrial production of building materials today, a trend is outlined for the use of non-traditional types of energy, and mainly solar energy at the stage of heat treatment, where steam heating was traditionally used.

In these researches, development in the direction of temperature treatment of polystyrene concrete was considered. The purpose of the research is the development and practical implementation of the technology of production of polystyrene using solar energy. The results of the conducted researches confirmed that the usage of solar thermal treatment methods for the thermal treatment of polystyrene concrete is effective in weather conditions for the southern regions of the Republic of Kazakhstan which refers to areas with dry and hot climatic conditions. Detailed studies of polystyrene concrete under high-temperature weather conditions have been carried out and introduced into production. The usage of heliotechnology for the production of polystyrene concrete improves the quality of manufactured products, also makes it possible to reduce the energy costs of traditional energy covered by the use of solar energy.
\end{abstract}

\section{Introduction}

A wide variety of traditional fuels is used in industry nowadays. Natural gas, oil, coal, etc., and they are all classified as non-renewable sources of energy. Traditional types of fuels

* Corresponding author: ecoeducation@mail.ru 
have certain reserves and the range of their possible application will be uniquely dictated by the rates of consumption. The tendency towards to unconventional energy occurring around the world is explained both by the possibility of ending the stock of traditional types of energy, as well as by the critical situation of the environment caused by the burning of organic fuels and the emergence of a "greenhouse" effect.

Nowadays, numerous research works have been done on the use of solar energy for heat treatment of concrete in the CIS and abroad and great experience in solar thermal treatment of products and structures in production conditions has been gained [10,11]. One of the initial aspects of using solar power for the processing of concrete products and structures with heat is the use of solar systems with a circulating intermediate coolant. In this case, the flux of solar radiation during the heating of products does not act on concrete, but on the solar collectors in which the intermediate coolant circulates (oil, water, etc.), and it is generally assumed that it is not heliothermal processing of concrete products, but heat treatment of materials using a heat carrier heated by solar energy. The aim of the research is to develop a technology for the production of polystyrene concrete with heat treatment through the use of solar energy.

The production method of polystyrene concrete products consists of foaming of polystyrene granules, drying of the polystyrene beads, dosage of raw materials components, production of polystyrene concrete, molding of polystyrene concrete, hardening of polystyrene concrete in solar polymer chambers, and cutting the concrete blocks into smaller blocks.

Heat treatment by methods of solar thermal treatment is carried out under helio-lids or in translucent chambers of various constructive solutions. The helio-lid must fit snugly against the sides of the mold and join with the sides of the mold with locking devices. The structure of the helio-lid should provide with: the height of the distance between the surface of freshly formed concrete and the lower part of the helio-lid should not be more than 20-30 $\mathrm{mm}$. In the form of a translucent material the following are used: - polyethylene uncoated stabilized membrane of the type SIC, ST, T, M (ST 10354-82) with a thickness of 100-300 mkm; - Polyvinylchloride membrane of technical grade B (ST 16272-79) with a thickness of $230 \mathrm{mkm}$ - PVC (B); - glass with a thickness of 4-6 mm.

A new method which combines the heat treatment of conventional concrete and polystyrene concrete by means of heliosystems with circulating intermediate coolant at landfills and in closed shops has been developed [1]. The invention consists in producing of high-quality polystyrene concrete products and constructions all year round, effectively using of solar energy in the autumn-spring and winter seasons of the year using all year solar systems with a circulating intermediate coolant, as well as using traditional types of energy in the absence of solar energy. In this case, the heliocamera or helioform with the product under the helio cover pass (HT) heat treatment in the summer seasons of the year under heliopoligon conditions, as well as in the autumn-spring-winter periods of the year, and a year-round solar system with an intermediate coolant will be connected in the absence of solar radiation. Thermal solar treatment passes through soft modes at a maximum temperature of $70^{\circ}$ degrees in the chamber or under the helio cover with an increase in the rise temperature of 4-7 hours, a conditional isothermal aging of the product for 6-7 hours, and cooling to $35^{\circ} \mathrm{C} .100 \%$ humidity is created in the chamber due to the fact that water is poured onto the bottom of the chamber. The strength of concrete is $50-70 \%$ $\mathrm{R}_{28}$ for 24-hour, 1 . This method of thermal solar treatment of polystyrene concrete products will give year-round heat treatment, the possibility of saving of $50-100 \%$ of traditional fuels, environmentally friendly nature, high quality of manufactured products and constructions. Thermal solar treatment (TT) through a solar system with the use of an intermediate heat carrier was developed for polystyrene concrete [1]. Nowadays, the 
relevance of the decision is heat treatment of almost all types of concretes, including light ones with using non-traditional energy of solar energy.

New methods of organizing of solar thermal treatment technologies for different types and types of concrete products in the dry hot environment of the south region of the Republic of Kazakhstan will allow saving 50-100\% of traditional types of fuel environmentally friendly nature without emissions from fuel combustion, high quality and low cost of concrete products and structures $[9,12,13]$.

\section{Materials and methods}

In the manufacture of concrete products with helio-thermal processing using film-forming substances, polymeric translucent of solar cells as binding materials are recommended to use portland cement grades 400 and above and they meet the standards of ST 10178-85, ST 22266-78. The most effective are quick-hardening portland cement and slag portland cements, as well as cements which activity while steaming according to ST 310.4-81 and BR 5.01.23-83 is equal to the following values: At cement grade 400-24 MPa, the same 500-28 MPa, the same 550, 600-33MPa.

In high temperature conditions, sulfate-resistant portland cement with a mineral additive of the mark M400 from Shymkent and Karaganda factories was used. Fillers (crushed stone, gravel, sand) do meet the requirements of ST 10268-80 and ST 26633-85. Quartz sand of three batches was taken as a fine aggregate. The bulk density of sand of these lots is 1550,1526 and $1448 \mathrm{~kg} / \mathrm{m} 3$; the amount of clayey and pulverized was accordingly not higher than $2.2 ; 1.7 ; 0.4 \%$. The used sands satisfy the state standards 8736-77.

Crushed limestone and granite stone fractions 5-20 mm were used as an aggregate. The density of limestone crushed stone is $1291 \mathrm{~kg} / \mathrm{m} 3$, and the density of granite crushed stone is $1393 \mathrm{~kg} / \mathrm{m} 3$, the grain compounds of large aggregates are given in the following Table 5 . Grain compositions of large aggregate are determined in accordance with the State standards 8269-82. The content of clayey, dust-like particles in all cases did not exceed 0.4$0.7 \%$. The fillers satisfy the State standards 8267-82.

When polystyrene concrete was produced with a large aggregate, the expanded polystyrene of fraction $\varnothing 5$ was chosen. The technical conditions for polystyrene gravel are given in the following Table 1.

Table 1. Technical specifications for polystyrene

\begin{tabular}{|l|c|c|}
\hline \multicolumn{1}{|c|}{ Parameters } & TS & $\begin{array}{c}\text { By the results of } \\
\text { analysis }\end{array}$ \\
\hline \multicolumn{1}{|c|}{1} & 2 & 3 \\
\hline Water \% by weight in beads & 1,1 & 1,86 \\
\hline Grading compound: & 1,1 & 0,2 \\
\hline Average particle diameter, mm & 1,1 & 0,2 \\
\hline $\begin{array}{l}\text { Residue on a sieve with a hole diameter }(\mathrm{mm}), \%: \\
2,5\end{array}$ & 2,1 & 0,2 \\
\hline Residue on a pallet after sieving on a 0.8 mm sieve & $16-31$ & $13-16$ \\
\hline Apparent density, $\mathrm{kg} / \mathrm{M}^{3}$ & $1,4-2,86$ & 1,59 \\
\hline $\begin{array}{l}\text { The ultimate strength at static bending at the } \\
\text { indicated apparent density of kgf/cm2 is not less } \\
\text { than }\end{array}$ & & \\
\hline
\end{tabular}

The designing of composition of the polystyrene concrete was carried out by the calculation-experimental method $[5,6]$. There was set a task to produce heat-insulating 
polystyrene concrete of B0,5-B1 classes with average densities of $250-800 \mathrm{~kg} / \mathrm{m} 3$. Any calculated composition was corrected during the solar thermal treatment, taking into account the influence of temperature and the degree of dilution of the polystyrene-concrete mixture on the forming structure [2,3,4]. The dosage of the components of polystyrene concrete was carried out for cement by weight, for quartz sand by volume and weight, for polystyrene, water and additives by volume. The components were mixed during the one minute in a dry state, and additionally 4 minutes with the addition of water. The mobility of the polystyrene concrete mixture was determined after 5 minutes later the mixing was completed in accordance with the state standards 10181.1-81. Developed polystyrene concrete is on fast-hardening portland cement. The following compositions were adopted (Table 2).

Table 2. Coponents of polystyrene concrete

\begin{tabular}{|c|c|c|c|c|c|}
\hline \multicolumn{6}{|c|}{ Coponents of polystyrene concrete } \\
\hline $\begin{array}{c}\text { Cement } \\
\text { FSC } \\
\text { M500 } \\
\text { kg/m } \mathrm{m}^{3}\end{array}$ & $\begin{array}{c}\text { Foamed } \\
\text { polystyrene } \\
\text { l/m³, Ø } 5\end{array}$ & $\begin{array}{c}\text { Sand } \\
\text { quartz, } \\
\text { kg/m } \mathbf{m}^{3}\end{array}$ & $\begin{array}{c}\text { Water, } \\
1 / \mathbf{m}^{3}\end{array}$ & $\begin{array}{c}\text { Superplasticizer, } \\
\mathrm{C}-3 \mathrm{~kg} / \mathrm{m}^{3}\end{array}$ & $\begin{array}{c}\text { Beaded } \\
\text { polystyrene } \\
(\text { PNG) kg/m }\end{array}$ \\
\hline 200,0 & 850,0 & 150,0 & 80,0 & 0,8 & 3,0 \\
\hline
\end{tabular}

The following methods were used while studying the properties of concrete mixtures and concrete structures. The characterized by mobility workability was determined by the standard cone in accordance with the state standard 10181.1-81. At the same time, a sample of the mixture was taken from the mixture of the concrete mixture twice, the sediment of the cone was measured, and the average value was taken. The consolidation of a concrete mixture with a vibration duration of 40 seconds was carried out on the vibrating table, if the vibration was increased, separation of the solution from the aggregate in the mixture began. Freshly molded samples remained in helioforms in solar polymer chambers for about 22-24 hours, after which the disintegration was done, and samples were placed in the finished goods warehouse.

The class of concrete was determined by compressing of standard sample cubes with dimensions of $150 \times 150 \times 150(100 \times 100 \times 100) \mathrm{mm}$ molded according to the developed technology. The experiments were conducted during the 28 day interval according to the state standard 10180-90. The experiments to determine the density of concrete were carried out for a series of concrete samples by weighing according to the state standard 7005-86.

The consumption of portland cement with the amount of $180-400 \mathrm{~kg} / \mathrm{m} 3$ was taken to obtain the required grade for the density of polystyrene concrete, and also according to the brand of expanded polystyrene and sand. The consumption of quartz sand was assigned according to the conditions for the filling of gaps between the grains in the polystyrene concrete mixture. The consumption of water was assumed based on the projected workability of concrete mixes. The strength for axial compression was determined on samples of cubes like 100x100x100 mm.

The thermophysical parameters of the experimental concrete were determined by the following method: polystyrene concrete samples of the requested density with the size of 150x150x150 mm, they were dried according to the the state standard 7076 requirement for thermal conductivity, after which the thermal conductivity was measured by the IT-1 device "Fenix-center" of the city of Cherepovetc.

Study of the structure of cement stone. Whilen studying the cement stone of polystyrene concrete, differential thermal, x-ray, microscopic analyzes were used. The degree of hydration of clinker minerals was carried out by a differential thermal method $[7,8]$. Radiographic study was carried out on cement, cement powder polystyrene concrete for 1 
day, 28 diurnal age. The porosity index of the cement stone was determined in accordance with the state standard 12730.4.

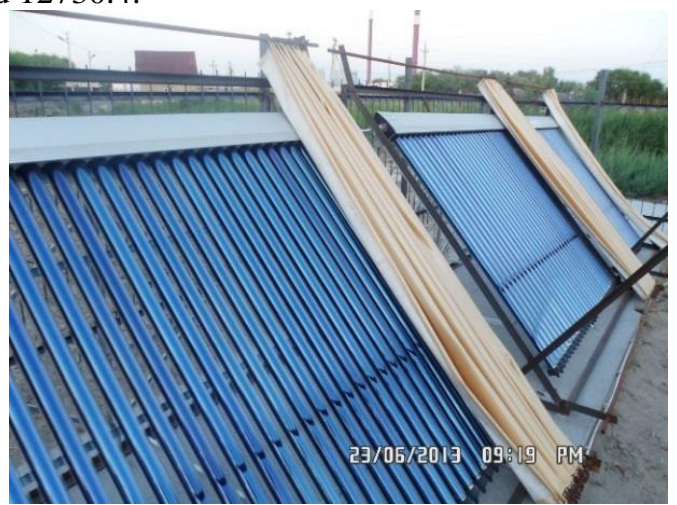

Fig.1. Solar system with a circulating intermediate coolant. Pilot plan

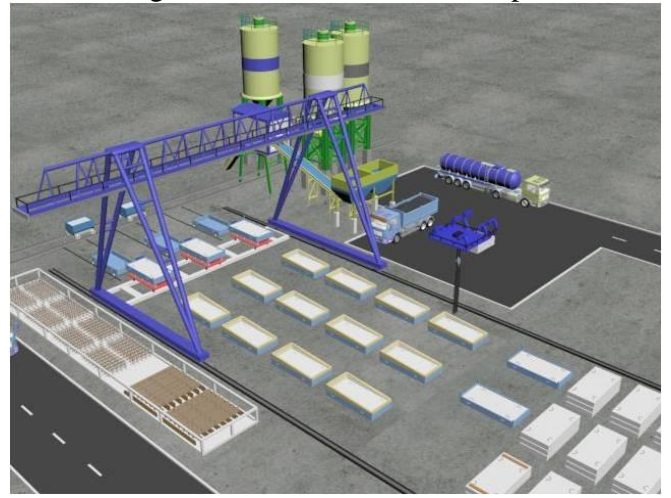

Fig.2. Diagram of an open heliopoly of polystyrene concrete products

\section{Results}

For studying the kinetics of hardening of polystyrene concrete there were made samples of grades D600, D500, D450, D400, D350, D340, D300; D250. Instead of a piece of quartz sand polystyrene beads were introduced. Figure 3 shows the increase in the strength of polystyrene concrete of the types of D800, D500, D350 helio-thermal grades in a solar helichamber. The figure 4 shows the increase in the strength of polystyrene concrete samples in a natural environment at the same average density. It can be seen from the graphs that for specimens of identical average densities the strength of heat-treated samples in a solar chamber is higher than that of the pistobrel-concrete samples formed in a natural climate by $50-100 \%$. On the basis of this the structure of the investigated samples remained fairly good, there were no visible bundles. The interval of the duration of solar thermal treatment is 22 hours. Modes of solar thermal processing are universal for polystyrene concrete of D800, D500 and D350. 

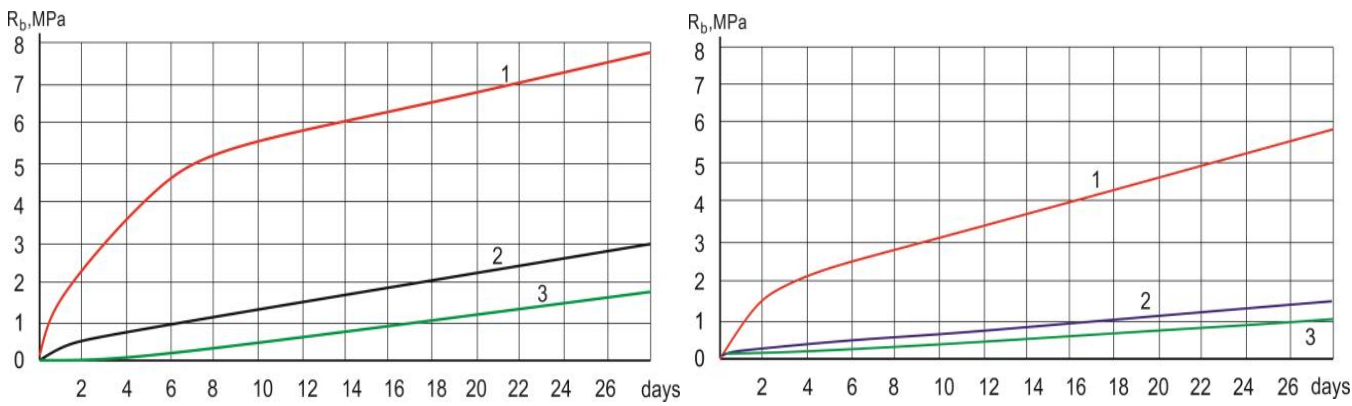

Fig.3. Growth strength of polystyrene concrete after heliothermal treatment, at the FSC. 1- polystyrene

Fig.4. Growth of strength of polystyrene-concrete solidification at the FSC M500. 1- polystyrene concrete D800, 2-polystyrene concrete D500, 3concrete D800, 2-polystyrene concrete D500, 3polystyrene concrete D350. polystyrene concrete D 350

Polystyrene concrete samples of types D800 achieve in a transparent chamber with a solar system with an intermediate heat carrier of $7.9 \mathrm{MPa}$, whereas in a normal environment it is 5.6 MPa; samples of the type D500 achieve in a transparent chamber with an intermediate heat carrier of $3 \mathrm{MPa}$, and in a normal environment of $1.1 \mathrm{MPa}$; polystyrene concrete of type D350 reaches in a transparent chamber with a solar system with an intermediate heat carrier of $2.8 \mathrm{MPa}$, and in a normal environment it is $0.9 \mathrm{MPa}$. The new methods of combined solar thermal treatment in translucent solar cells with the use of a heliosystem with an intermediate coolant and additional conventional energy sources for polystyrene concrete in a thermal chamber using film-forming compositions of freshly molded concrete applied to the surface make it possible to achieve high strength parameters.

Frost resistance of polystyrene concrete. There is a need to study the index of frost resistance of conventional concrete in connection with the planned usage of solar thermal treatment of concrete constructions in various regions of the Republic of Kazakhstan.

One of the most important technical characteristics of concrete constructions is its frost resistance. Frost resistance of concrete constructions is determined by its structure, especially by the nature of porosity, because the latter will determine the location of frozen water in the body of the material at minus temperatures, and hence the magnitude of the emerging stresses and the speed of the loosening process of the concrete structure.

The frost resistance of polystyrene concrete is in the range of 75-100 cycles of freezing and thawing, Table 3.

Table 3. Frost resistance of polystyrene concrete

\begin{tabular}{|l|l|l|l|l|l|l|l|}
\hline $\begin{array}{l}\text { Density of } \\
\text { grade } \\
\text { polystyrene } \\
\text { concrete }\end{array}$ & D300 & D350 & D400 & D450 & D500 & D550 & D600 \\
\hline $\begin{array}{l}\text { The types } \\
\text { of } \\
\text { polystyrene } \\
\text { concrete for } \\
\text { frost } \\
\text { resistance }\end{array}$ & F35-F50 & F35-F50 & F50-F75 & F75-F100 & F75-F100 & $\begin{array}{l}\text { F100- } \\
\text { F150 }\end{array}$ & F100- \\
\hline
\end{tabular}

Thermal conductivity of polystyrene concrete. "The state standard 51263-99 was used for testings on the thermal conductivity of polystyrene concrete. Polystyrene concrete. Technical conditions». Polystyrene-concrete samples were formed in metal forms measuring 150x150x150 mm. The composition of the taken polystyrene concrete is the 
following: portland cement - FSC M500, expanded polystyrene granules - $(\gamma=15 \mathrm{~kg} / \mathrm{m} 3)$, quartz sand $-\gamma=1572 \mathrm{~kg} / \mathrm{m}^{3}$, drinking water, superplasticizer C-3, polystyrene nonexpanded granulated. Soft modes of solar thermal treatment in solar cells with a filmforming substance are applied in the experiments, the samples are heated to $-50-600^{\circ} \mathrm{C}$, cooled to $30-350^{\circ} \mathrm{C}$. The thermal conductive properties of polystyrene concrete of grades D245, D300, D400 were measured with an instrument for determining the heat-conducting indicators of IT-1 of the Cherepovetc branch of the Phoenix Center of the Vologda Research and Production Association. The range of measurements of the thermal conductivity of this device is in the range from 0.04 to $1.0 \mathrm{~W} / \mathrm{m}^{2}{ }^{0} \mathrm{C}$, the temperature scale of measurements lies in the range from $-30^{\circ} \mathrm{C}$ to $+50^{\circ} \mathrm{C}$, the limit of the permissible error of measurements can be in the region of $10 \%$. The thermal conductivity was measured on prototypes of polystyrene concrete (Table 4).

Table 4. Indicators of thermal conductivity of polystyrene concrete

\begin{tabular}{|c|c|c|c|c|}
\hline $\begin{array}{c}\text { Type } \\
\text { according to } \\
\text { density of } \\
\text { polystyrene } \\
\text { concrete }\end{array}$ & $\begin{array}{c}\text { Sample 1, } \boldsymbol{\lambda}, \\
\mathbf{W} / \mathbf{m}^{\mathbf{2}}{ }^{\circ} \mathbf{C}\end{array}$ & $\begin{array}{c}\text { Sample 2, } \boldsymbol{\lambda}, \\
\mathbf{W} / \mathbf{m}^{\mathbf{2}}{ }^{\circ} \mathbf{C}\end{array}$ & $\begin{array}{c}\text { Sample 3, } \boldsymbol{\lambda}, \\
\mathbf{W} / \mathbf{m}^{\mathbf{2}}{ }^{\circ} \mathbf{C}\end{array}$ & $\begin{array}{c}\text { Average } \\
\text { value, } \boldsymbol{\lambda}, \\
\mathbf{W} / \mathbf{m}^{\mathbf{2}}{ }^{\circ} \mathbf{C}\end{array}$ \\
\hline D 400 & 0,103921 & 0,104951 & 0,104971 & 0,104611 \\
\hline D 300 & 0,080021 & 0,079122 & 0,081219 & 0,080110 \\
\hline D 245 & 0,073202 & 0,073122 & 0,074487 & 0,073637 \\
\hline
\end{tabular}

Thermal conductivity of heat-treated polystyrene concrete by the method of solar thermal treatment is applicable to the requirements of thermal insulation of constructions.

Investigation of the structure and phase formation of cement polystyrene concrete. Electron microscopy studies of the samples of polystyrene concrete were carried out on a scanning electron microscope-microanalyzer Jeol JSM-6490 LA. Preparations were prepared according to a standard procedure without metallic shading of the surface. The accelerating voltage at the anode composed $7 \mathrm{kV}$. At least 100 sites were viewed, the most typical ones of which were selected. The set of magnifications was chosen as follows: $\mathrm{x} 500,2,000$ and 5,000 times.

Radiography. X-ray researches of polystyrene concretes were performed on an X-PertPRO diffractometer using a complex of computer programs of this apparatus. The samples were prepared by the powder method for phase analysis.

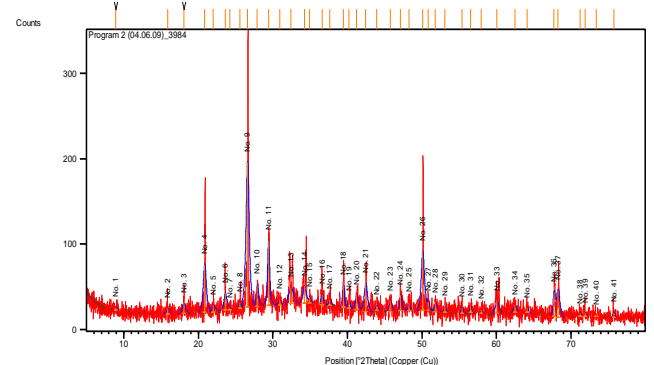

Fig.5. Radiography pattern of sample No 1 of polystyrene concrete. Heat treatment under the sun under the membrane. 


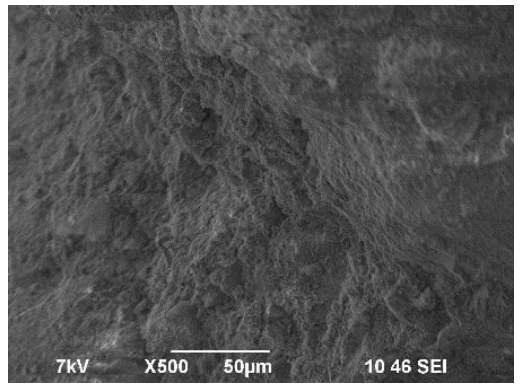

Fig.6. Morphology of the sample № 1, section 1 $\mathrm{x} 500$, SEM of polystyrene concrete. Heat treatment under the sun under the membrane

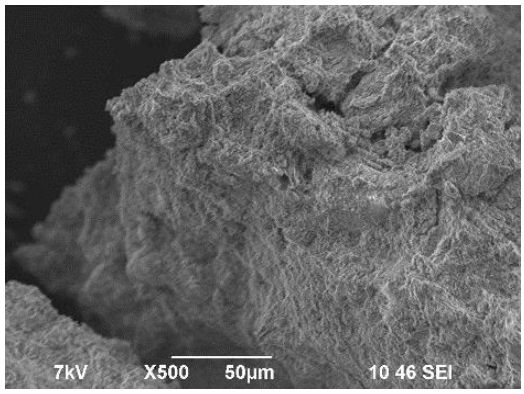

Fig.7. Morphology of the sample No 1, section 2 $\mathrm{x} 500$, SEM of polystyrene concrete. Heat treatment under the sun under the membrane

Table 5. Results of semi-quantitative phase analysis of sample No.1 of polystyrene concrete. Heat treatment under the sun under the membrane

\begin{tabular}{|c|c|c|c|c|}
\hline $\mathbf{N}$ & Ref. Code & Compound Name & Chemical Formula & SemiQuant [\%] \\
\hline 1 & $01-086-0402$ & tricalcium silicon pentaoxide & $\mathrm{Ca}_{3} \mathrm{Si} \mathrm{O5}$ & 26 \\
\hline 2 & $01-089-6427$ & sodium tecto-alumotrisilicate & $\mathrm{Na}\left(\mathrm{Al} \mathrm{Si}_{3} \mathrm{O}_{8}\right)$ & 28 \\
\hline 3 & $01-083-0539$ & Quartz, syn & $\mathrm{Si} \mathrm{O}_{2}$ & 46 \\
\hline
\end{tabular}

Note - The results of phase analysis of the roentgenogram _ 3984 (Figure 5), where No. is the number of the identified phase, Ref. Code-number of the identification card, Compound Name is the name of the phase, Chemical Formula is a chemical formula, the amount of the selected phase is shown in percent.

Table 6. Results of semi-quantitative phase analysis of the sample No.2 of polystyrene concrete. Thermal treatment in a solar cell.

\begin{tabular}{|c|c|c|c|c|}
\hline $\mathbf{N}$ & Ref. Code & Compound Name & $\begin{array}{c}\text { Chemical } \\
\text { Formula }\end{array}$ & $\begin{array}{c}\text { SemiQuant } \\
{[\%]}\end{array}$ \\
\hline 1 & $01-085-0795$ & Quartz, syn & $\mathrm{SiO} 2$ & 16 \\
\hline 2 & $01-073-0599$ & tricalcium silicate oxide & $\mathrm{Ca} 3(\mathrm{SiO} 4) \mathrm{O}$ & 22 \\
\hline 3 & $01-070-1433$ & magnesium carbonate trihydrate & $\mathrm{MgCO} 3(\mathrm{H} 2 \mathrm{O}) 3$ & 11 \\
\hline 4 & $01-083-1612$ & albite, high, sodium tecto-alumotrisilicate & $\mathrm{Na}(\mathrm{Al} \mathrm{Si} 3 \mathrm{O} 8)$ & 31 \\
\hline 5 & $01-086-0402$ & tricalcium silicon pentaoxide & $\mathrm{Ca} 3 \mathrm{SiO} 5$ & 20 \\
\hline
\end{tabular}

Note - The results of phase analysis of the roentgenogram _ 3987 (Figure 8), where No. is the number of the identified phase, Ref. Code-number of the identification card, Compound Name is the name of the phase, Chemical Formula is a chemical formula, the amount of the selected phase is shown in percent. 


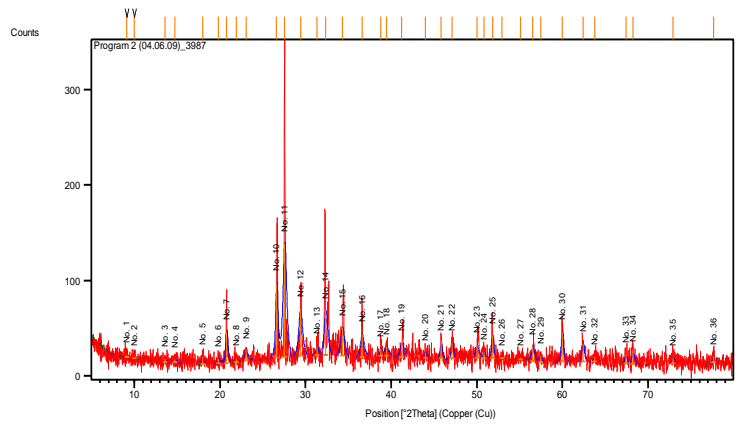

Fig.8. X-ray pattern of the sample No2 of polystyrene concrete. Thermal treatment in a solar cell.

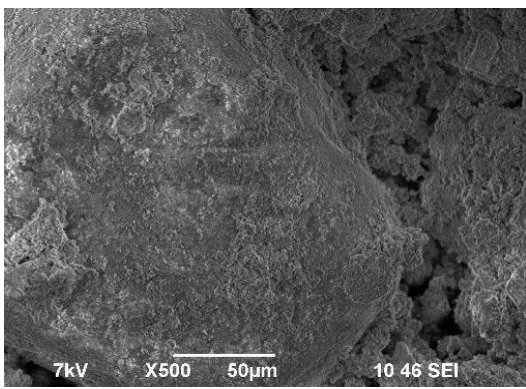

Fig.9. Morphology of the sample No.2, section 2, X 500, SEM, polystyrene concrete. Thermal treatment in a solar cell

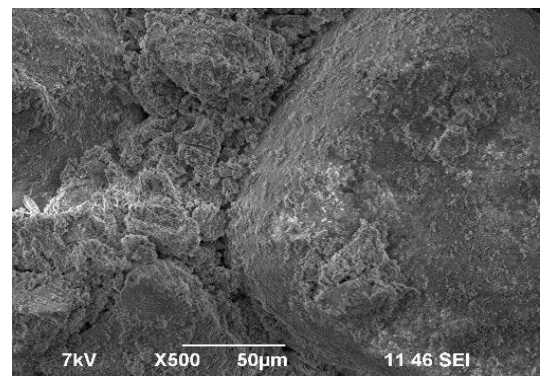

Fig.10. Morphology of the sample No. 2, section 1, X 500, SEM, polystyrene concrete. Thermal treatment in a solar cell

Results. X-ray diffraction data are summarized in the tables 5 and 6 . From the analysis of this table it follows that $\mathrm{SiO}_{2}$ is present in components of all samples. Then it should be further identified that Calcite $\mathrm{Ca}\left(\mathrm{CO}_{3}\right),(\mathrm{Mg} 0.03 \mathrm{Ca} 0.97)\left(\mathrm{CO}_{3}\right)$ and calcium and magnesium carbonates in the hydrated form of $\mathrm{MgCO}_{3}\left(\mathrm{H}_{2} \mathrm{O}\right)_{3}$.

It should also be noted the presence of calcium and magnesium silicates, aluminosilicates, aluminates, as well as iron sulfides. Analyzing the composition of the initial components of both polystyrene concrete and foam concrete, it is possible to conclude that the obtained results of the phase analysis of the samples presented for investigation are consistency.

In general, the data of X-ray diffraction analysis of cement stone and concrete obtained by a master student on the basis of the investigation of enveloping replicas by the methods of transmission electron microscopy also fits into the ideas developed earlier on the physico-chemical transformations that occur during the formation of concrete with a help of using various techniques and the introduction of some additives into the initial charge. However, the high magnification of the electron microscope transmission and the technique of enveloping replicas gave only indirect information about the microscale of the cement stone.

A direct investigation of the surface plane of some cement stone particles by the methods of scanning electron microscopy made it possible to obtain additional information to earlier data about the microspatter of the individual elements of structure over a wide range of magnitudes from 500 to 5000 times.

Taking back to the data of phase analysis as a fairly objective integral method of research and analyzing both like polystyrene concrete during heat treatment in a solar cell 
and heat treatment under the sun under the membrana, a difference is observed both in the phase composition of the mineral components and their quantitative ratio.

When analyzing the percentage of silica in polystyrene concrete after the solar chamber (2) and the heat treatment under the membrana under the sun (1), in case $1, \mathrm{Si} \mathrm{O} 2=46 \%$, in case $2, \mathrm{SiO} 2=16 \%$. $\mathrm{Ca} 3 \mathrm{SiO} 5$ is in the case of $1-26 \%$, and in $2-20 \%$. $\mathrm{Na}$ ( $\mathrm{Al} \mathrm{Si} 3 \mathrm{O} 8$ ) is in $1-28 \%$, and in $2-31 \%$. In addition, during the heat treatment under the sun under the membrana, phases of $\mathrm{Ca}_{3}\left(\mathrm{SiO}_{4}\right) \mathrm{O}$ and $\mathrm{MgCO} 3(\mathrm{H} 2 \mathrm{O})_{3}$ are additionally detected. The presence of tricalcium silicate oxide in an amount of up to $22 \%$ indicates that the process of interaction of sand and cement under conditions 2 is much more complete than in 1.

The presence in 2 magnesium bicarbonate in the amount of $11 \%$ also confirms that the conclusion about the differences in the processes occurring in polystyrene concretes prepared according to schemes 1 and 2. The morphology of polystyrene concretes according to the scheme 1 in comparison with the 2 (Figures 5, 6, 7 and 15) also demonstrates significant differences in the microsphere of the samples of polystyreneconcrete prepared by methods 1 and 2 . The samples 1 can be characterized as more homogeneous loose. Reinforced with needle crystals composites randomly oriented in an array of cement stone. The cement stone of the sample 2 is formed from layered aggregates, the surface of which is covered with fine polyhedral grains, with the size of $100 \mathrm{~nm}$ and individual flat flakes with sizes from 0.5 to $100 \mu \mathrm{m}$ and higher. Traces of reinforcing needles are oriented in approximately in the same direction (texture).

Conclusion by 2 samples of polystyrene concrete: 1.Difference in the phasemineralogical compounds, indicating the depth of the ongoing processes of formation of cement stone; Features of the morphology of cement stone, as a composite of polyhedral crystals reinforced with needle-like crystal and their chaotic orientation in space for 1 sample; 3. A layered micromaterial of cement stone with the reinforcement of needle crystals textured relatively to the layers. Research of thermal processing of polystyrene concrete in translucent chambers with and without the usage of an intermediate coolant carried out on the materials and compositions indicated in the Table 2. Heat treatment was carried out on blocks of 200x300x600 mm. Figure 11.

Table 7. Solar thermal treatment of products using a film-forming substance in a light-transparent chamber with a solar system and an intermediate coolant.

\begin{tabular}{|c|c|c|c|}
\hline $\begin{array}{c}\text { Points for } \\
\text { measuring the } \\
\text { temperature in } \\
\text { products }\end{array}$ & \multicolumn{2}{|c|}{ Temperature of concrete, ${ }^{\mathbf{0}} \mathbf{C}$} & $\begin{array}{c}\text { Total number of degree and } \\
\text { hours }\end{array}$ \\
\cline { 2 - 4 } & max & In the end of cycle & \\
\hline 1 & 60 & 28 & 869 \\
\hline 1 & 59 & 28 & 864 \\
\hline 2 & 58 & 27 & 860 \\
\hline 2 & 59 & 26 & 858 \\
\hline 3 & 58 & 27 & 853 \\
\hline 3 & 57 & 26 & 856 \\
\hline Note - in the course of the experiment the temperature of air was in the range of $36-25^{\circ} \mathrm{C}$ \\
\hline
\end{tabular}




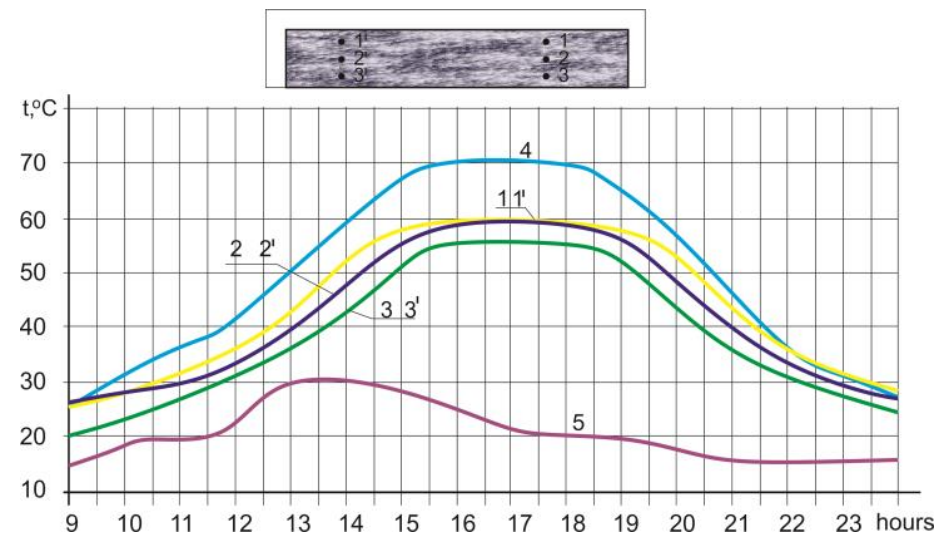

Fig.11. Changes in the temperature of the PAG-18 plates and cube samples during their solar thermal treatment in translucent solar cells under a film-forming composition with an intermediate coolant. 1', $2,2^{\prime}, 3,3^{\prime}$ - location of thermocouples in polystyrene concrete; 4 - temperature of the intermediate coolant; 5 - air temperature

Solar thermal treatment of polystyrene concrete blocks with application of a film-forming substance in a light-transparent chamber with an intermediate coolant was heated to a maximum of $52-53{ }^{\circ} \mathrm{C}$, cooling to $28-27{ }^{\circ} \mathrm{C}$. The temperature of the intermediate coolant reached $69-68{ }^{\circ} \mathrm{C}$. The degree of maturity was $1000-950$. The degree of maturity of polystyrene concrete during solar thermal treatment in a light-transparent chamber with an intermediate coolant is $15-20 \%$ higher than concrete of helio-thermal processes under a film-forming composition in natural conditions.

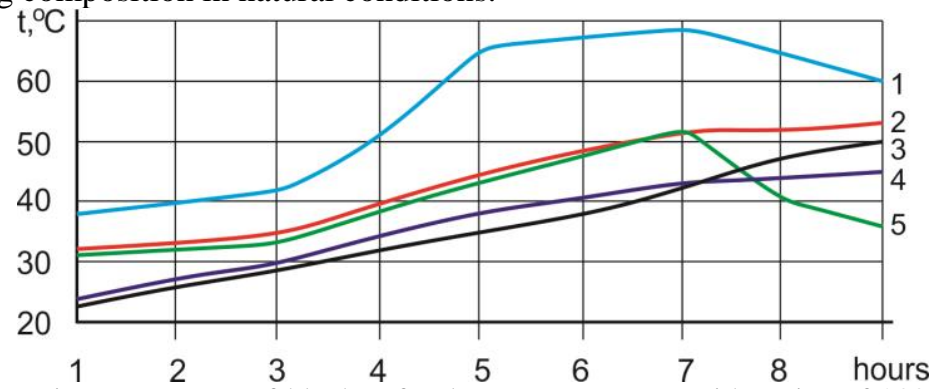

Fig.12. Changes in temperature of blocks of polystyrene concrete with a size of 200x300x600 mm during their solar thermal treatment. 1 - temperature of the intermediate coolant, 2-temperature in polystyrene concrete in a translucent solar chamber under a film-forming substance with a solar system with an intermediate heat carrier, 3- temperature in polystyrene concrete in a transparent chamber with a solar system and an intermediate coolant, 4- temperature in polystyrene concrete under a film-forming composition in natural conditions, 5- temperature in polystyrene concrete in a translucent chamber in natural conditions

\section{Discussions}

The studied ways of consumption of solar energy for accelerated solidification of polystyrene concrete products at the factory indicate a significant profitability of replacing traditional fuels with unconventional energy carriers. The investigated new technology is compared with the basic technology. The choice as a basic method of steam heating in steam chambers compared to the new technology in solar cells showed high efficiency of the latter. The results of the made research are tested at the factories of production of polystyrene concrete blocks at the stage of heat and solar energy treatment. Thus, the 
developed method of heat treatment, the solar thermal treatment of products with the help of using of film-forming composition makes it possible to save not to use traditional steam heating in hot season in a 200-day period a year, and in the cold season by using a combined method it possible to save up to $80-100 \mathrm{~kg}$ of fuel equivalent (conventional fuel), about 0,6 tons of water per $\mathrm{m}^{3}$ of products, and at the same time the savings amount to $3120-3220$ tenge $/ \mathrm{m}^{3}$ of products and will provide a daily turnover of forms. The actual economic effect in the manufacture of $1000 \mathrm{~m}^{3}$ of blocks with combined solar thermal treatment with the use of a film-forming composition was 3,223,040 tenge.

\section{Conclusions}

As a result of the research work the technology of polystyrene concrete production with heat treatment due to solar energy was developed. In the course of the research work, the tasks set in the work were completely solved-the relationship between the period of solar energy supply during solar thermal treatment and the increase in the strength of polystyrene concrete was determined; the effect of the flow of incoming solar energy on the nature and alignment of temperature fields in helium-processed products from polystyrene concrete of different massiveness and surface area was revealed; the characteristic features of the structure and the most important qualities of the investigated polystyrene concrete, which have a qualitative structure and are similar to the samples hardened under normal conditions; frost resistance of the resulting polystyrene concrete are within 75-100 cycles of freezing and thawing; thermal conductivity of polystyrene heat-treated according to the developed meets the requirements of thermal insulation of structures.

\section{References}

1. Aruova L.B. Innovative patent for invention No. 25072. Method of heat treatment of building products from polystyrene concrete mixture. Kazpatent. (2015)

2. Wenbo Shi, Linchang Miao, Junhui Luo, Jiaqi Wang, and Yinan Chen Durability of Modified Expanded Polystyrene Concrete after Dynamic Cyclic Loading. Shock and Vibration Volume (2016), Article ID 2391476, 7 pages http://dx.doi.org/10.1155/2016/2391476 Institute of Geotechnical Engineering, Southeast University, Nanjing 210018, China

3. Rahim, J. A., Hamzah, S. H., \& Saman, H. M. Expanded polystyrene fibred lightweight concrete (EPSF-LWC) as a load bearing wall panel // Jurnal Teknologi, 76(9), 81-85. (2015)

4. B.A. Herki \&J.M. Khatib Valorisation of waste expanded polystyrene in concrete using a novel recycling technique. Journal European Journal of Environmental and Civil Engineering. Volume 21, 2017 - Issue 11. Pages 1384-1402 | Received 28 Mar 2015, Accepted 22 Mar 2016, (Published online: 15 Apr 2016)

5. 5.Behnam Vakhshouri \&Shami Nejadi Review on the mixture design and mechanical properties of the lightweight concrete containing expanded polystyrene beads. Journal Australian Journal of Structural Engineering. Volume 19, - Issue 1. (2018)

6. Bengin Herki Absorption Characteristics of Lightweight Concrete Containing Densified Polystyrene// Civil Engineering Journal.- Home Vol 3, No 8 (2017)

7. Gusev B.V. Kuznetsova T.V. Cement and concrete - development trends // Publisher: The scientific world. ISBN: 978-5-91522-275-4. -136p. -(2012)

8. Gusev B.V., Falikman V.R. Structural Concrete In The Age Of Sustainable Development // Special Publication. Volume 305. Appears on pages(s): 36.1-36.12. American Concrete Institute, ACI Special Publication . Scopus- Impact Factor 1,27. (2015) 
9. Aruova L.B., Dauzhanov N.T. Technology of using solar energy in the production of various types of concrete. Journal of Concrete Technology. ISSN: 1813-9787 - No12.P.31-36. -(2014).

10. Podgornov N.I. Heat treatment of concrete using solar energy // Moscow: publishing house ABC, 2010.-328p.

11. Aruova L.B., Dauzhanov N.T. Energy and Resource Saving Technologies of Building Materials Production Using Solar Energy // MOJ Civil Engineering, Volume 3 Issue 3, pages 1-7, ISSN 2572-8520. (2017),http://medcraveonline.com/MOJCE/MOJCE-0300068.php

12. Aruova Lyazat, Dauzhanov Nabi University named after Korkyt Ata // Mediterranean Journal of Social Sciences the Vol 5 No 23. Rome, Italy. Process parameters of production of non-autoclaved aerated concrete on the basis of complex use of ash and gypsum-containing wastes. Rome, Italy. (2014). Web: www.mcser.org. ScopusImpact Factor 0,1.

13. Aruova L.B. Manufacturing Arbolitic Building Products Using Solar Energy // Journal of Mechanical Engineering Research \& Developments (JMERD) 41(2) 49-55, ISSN: 1024-1752. (2018) 